\title{
Modern-DAY CRUSADERS IN EUROPE. Tradition, FAMILY AND PROPERTY:
}

ANALYSIS OF A TRANSNATIONAL, ULTRA-CONSERVATIVE, CATHOLIC-INSPIRED INFLUENCE NETWORK

\section{Neil Datta}

European Parliamentary Forum for Sexual \& Reproductive Rights

\begin{abstract}
Three recent events affecting human rights in sexuality and reproduction (a proposed ban on abortion in Poland, blocking support for She Decides in Croatia and halting a civil union law in Estonia) were spearheaded by organizations which appear to be the national antennae of the transnational, socially conservative network called Tradition, Family and Property (TFP). TFP refers to a set of interrelated conservative, Catholic-inspired organizations which share a common world view inspired by the TFP founder, Plinio Corrêa de Oliveira. Originating in Brazil in 1960 and eventually spreading throughout the world, TFP has long been an insurrection movement within Catholicism, with a distinct way of working by fusing social conservatism with economic hyper-liberalism and a legacy of complicity with far-right movements. Having withered away from Latin America, TFP is now an active European network with positions against sexual and reproductive rights (SRR) among its priorities. TFP's influence on SRR takes three main routes: social mobilization; norm entrepreneur and entering decision-making spaces. TFP has found new horizons in Eastern Europe and ambitions to influence the European Union and the United Nations. The reactionary narrative of TFP espousing religious orthodoxy and sanctifying economic inequality could become attractive to some by offering religious legitimization for illiberalism and authoritarianism.
\end{abstract}

KEY WORDS: reproductive rights, ultra-conservatism, religious movements

\section{Author's contact:}

Neil Datta, European Parliamentary Forum for Sexual \& Reproductive Rights

Rue Montoyer 23,100o Brussels, Belgium.

E-mail: ndatta@epfweb.org 
POLITIČKE PERSPEKTIVE

ČLANCI I STUDIJE

\section{INTRODUCTION}

In the autumn of 2016, thousands of Polish women took to the streets in what became known as the 'Black Marches' to protest a draft law which would seek to implement a total ban on abortion, removing the few allowable cases where it was legally available under Poland's already restrictive law and even providing for the imprisonment of women who have an abortion (BBC 2016). In March 2017, the then Foreign Affairs Minister of Croatia, decided to take a position against the She Decides global fundraising initiative (Shedecides.com) on sexual and reproductive rights (SRR) and, further, to instruct Croatian diplomats to convince other European Union (EU) Member States to take a similarly hostile position (Despot, 2017). Earlier, in 2013, a petition gathering nearly 40,00o signatures in Estonia against same-sex unions forced the parliament to temporarily halt its deliberations on its civil partnership legislation (White 2013b).

While the three political events share a similar socially conservative objective, they appear otherwise unrelated, as they appear at different times, in different national contexts and on different issues. Closer inspection of the main protagonists involved in each, however, reveals some hitherto unknown connections. In Poland, the organization most prominently involved in promoting the abortion ban was the Fondacija Instytut na rzecz Kultury Prawnej Ordo Iuris (Foundation Institute for Legal Culture 'Ordo Iuris'). Ordo Iuris drafted the legislation under consideration and both presented and defended it before parliament and to the public. In Croatia, individuals affiliated with the organization Vigilare gained privileged access to the Minister for Foreign Affairs to encourage him to adopt a more traditionalist perspective in Croatia's diplomacy. In Estonia, the initiator and promoter of the petition which reached over 500,000 of Estonia's 1.2 million citizens was the organization Sihtasutus Perekonna ja Traditsiooni Kaitseks (SPTK - Foundation for the Protection of Family and Tradition). All three organizations, Ordo Juris, Vigilare and SPTK, appear to be the national antennae of the transnational, socially conservative, Catholicinspired lay organization called Tradition, Family and Property (TFP).

TFP refers to a set of interrelated conservative, Catholic-inspired lay organizations which share a world view inspired by the TFP founder, the $2 \mathrm{O}^{\text {th }}$ century Brazilian landowner and politician, Plinio Corrêa de Oliveira. TFP-related organizations go by the name TFP in their own country or by another name, often related to a socially conservative cultural cause. They number over 40 separate organizations across over dozens of countries and several continents. This article attempts to understand the extent of the TFP network in Europe and how it works to influence sexual and reproductive rights (SRR). 
NEIL DATTA

MODERN-DAY CRUSADERS IN EUROPE. TRADITION, FAMILY AND PROPERTY:

ANALYSIS OF A TRANSNATIONAL, ULTRA-CONSERVATIVE, CATHOLIC-INSPIRED INFLUENCE NETWORK

\section{TFP ORIGINS AND IDEOLOGY}

If the Revolution is disorder, the Counter-Revolution is the restoration of order. And by order we mean the peace of Christ in the Reign of Christ, that is, Christian civilization, austere and hierarchical, fundamentally sacral, anti-egalitarian, and anti-liberal. ${ }^{1}$

Plinio Corrêa de Oliveira, Revolução e Contra-Revolução, in Catolicismo, April 1959

Plinio Corrêa de Oliveira (1908-1995) was a wealthy, conservative, Catholic landowner in Brazil who served in Brazil's parliament and then went on to found TFP in 196o. A first characteristic of the movement is that TFP has a dual nature: spiritual and temporal. On the one hand, it can be seen as a similar conservative, religious movement to channel the motivation of lay Catholics as Opus Dei in Spain, Communion and Liberation in Italy and the Legion of Christ in Mexico, and, like these movements, TFP spread across the world from its native Brazil. On the other hand, TFP is also a politically active social movement focusing on the areas which Corrêa de Oliveira identified as the two main enemies of the Church in the 1960s: from within the Church, the enemy was liberation theology and other 'modernist' tendencies (which undermined the traditions of the Church) (Corrêa de Oliveira 1974), and from outside the Church, it was Communism, which advocated for agrarian reform (posing a threat to large landowners) (Corrêa de Oliveira 1985).

The doctrine of TFP is best described by its very name. By 'tradition', TFP opposes socially progressive evolutions in Catholic teachings - for example, some of the reforms of Vatican II - and advocates for the Church to remain true to its traditions in terms of social teachings and religious rites. While TFP opposes modernist tendencies in the Church and falls within the traditionalist faction of Catholic movements, it is not in open schism with Rome, as some other groups are, such as the Society for Saint Pious X (SSPX). ${ }^{2}$ By tradition, TFP also supports the historical primacy of the Church over the secular State. By 'family', TFP defends a traditionalist approach to marriage - namely, heterosexual, monogamous, patriarchal

1 Corrêa de Oliveira, Plinio. 1959 and 1977. "Revolução e Contra-Revolução”. Catolicismo, April 1959 (parts I and II) and January 1977 (part III): chapter III, part 1.

2 The SSPX, also referred to as 'Lefebvrists' after their founder, is a traditionalist Catholic movement which rejects the reforms of Vatican II. The clergy associated with the SSPX were excommunicated in the 1980 os and as such are considered 'out of communion' with Rome. They are regarded as hard-line, far-right and anti-Semitic (Splcenter.org). 
and geared towards procreation. As such, it opposes the legalization of divorce, contraception and abortion as well as same-sex relations. While this is standard fare for conservative, religious movements, TFP's position on property is unique. In defending private property ownership, TFP specifically means inherited wealth and privileges; it opposes the notion of socio-economic equality, which it considers dangerously Communist. As such, unlike many other conservative Christian groups, TFP can be described as not believing in the modern welfare State nor in the redistribution of wealth.

Corrêa de Oliveira was a prolific author and expounded on his world vision in his many works. ${ }^{3}$ Two works stand out: Revolution and CounterRevolution (Corrêa de Oliveira 1959) and The Nobility and Analogous Traditional Elites (Corrêa de Oliveira 1993). In Revolution and Counter-Revolution, Corrêa de Oliveira explains how the current ills of the world are the result of three past revolutions - namely, the Protestant revolution of the $16^{\text {th }}$ century, which challenged the primacy of the Catholic Church; the French Revolution of the $18^{\text {th }}$ century, which ushered in the dangerous ideas of 'equality' and 'liberty' and undermined the privileges of the nobility; and the Communist revolutions of the $20^{\text {th }}$ century, which endangered respect for private property itself and challenged the existence of God.

In Revolution and Counter-Revolution, Corrêa de Oliveira explains how TFP will lead the counter-revolution, resulting in an apocalyptic battle of good versus evil which he calls the bagarre (the battle) to restore an ideal society based on how he imagined the world prior to these revolutions namely, a society modelled on medieval Europe. Harking back to an idealized medieval past explains TFP's extensive use of medieval imagery - for example, the heraldic 'lion rampant' as its logo and the use of red capes and gold lion brooches as official dress for its members, who are themselves styled as 'warrior monks', and large red flag-staffs and banners emblazoned with the TFP gold lion. ${ }^{4}$

Nostalgic fascination with an imagined medieval Europe goes beyond inspiration for colourful imagery and branding, but forms the basis of TFP's vision of an ideal social hierarchy. In The Nobility and Analogous Traditional Elites, TFP advocates for a return of the former aristocracy and analogous traditional elites (for example, large property owners in Latin America) to their historic and rightful positions of power. Indeed, invoking religious legitimacy for this position, according to the pontifical texts discussed hereafter, the nobility is an elite from every point of view. It is

3 For Corrêa de Oliveira's many works, see: http://www.pliniocorreadeoliveira.info/livros. asp.

4 For an explanation of TFP's lion rampant visual, see: http://www.pliniocorreadeoliveira. info/DIS_SD_leao_TFP.htm\#.WkTxooxFxRo. 
the highest elite, not the sole elite. It is a species within the genus 'elites'.5 Such aristocrats would emerge after the bagarre to lead the world and thus save Western civilization by restoring authentic Christianity, all the while supported by the TFP warrior monks, while the rest of the population is reduced to a state of docile serfdom.

\section{THEORETICAL MODELS FOR TFP}

... it is difficult to understand how such a disjointed mixture of political reaction, religious intransigence and obscurantism could have flowered to the point that it enabled the TFP to reach out to the world, or at least to part of the Christian world of Western Europe, the United States and most of the countries of Latin America. ${ }^{6}$

TFP's polymorph nature as both a religious and politically engaged social movement as well as a trans-national network spanning six decades requires a unique theoretical approach anchored in at least two models. The first concerns TFP's religious personality as elaborated by Barker (2010), Compagnon (2008), Introvigne (2009), Mayer (1982), Matta (2008) and Zanotto (2017). The second field elucidate TFP development as a civil society movement as described by Power (2008), Ruderer (2012), Peñas Defago, et. al.(2018), Yamin, et. al. (2018), as well as Kuhar and Paternotte (2017).

Eileen Barker's work “The cult as a social problem” offers a theoretical framework for discussing new religious movements (NRM), often labelled as cults, and helps in understanding how TFP may be classified as NRM as a "religious or spiritual organisation with a predominantly first-generation membership." Barker also identified some of the common questions which NRM's must address including leadership, recruitment and ability to adapt. NRM's often confront suspicion, at times justified and at time not, from society at large and from the hierarchy of the religion from which they derive which helps situate TFP's standing within the wider Catholic world. Further, Matta (2008) explains in detail the case of the TFP in two Latin American countries and their specificity within the world of Catholic movements while Zanotto (2007) describes TFP as a 'complete organisation' adequately filling the many varied needs of its adherents.

However, Compagnon's work on Catholic movements in the $20^{\text {th }}$ century show how TFP is heir to an older tradition, that of Catholic fundamenta-

5 Ibid.

6 Latin America Report. 1985. “TFP Composition, Political Orientation, Training Discussed”. Joint Publication Research Service, Arlington, VA. 
POLITIČKE PERSPEKTIVE

ČLANCI I STUDIJE

lism. The concept of Catholic fundamentalism itself only becomes relevant when the mainstream of the Catholic world evolves to a new stage, leaving those who resisted in a minority position. TFP would thus be a NRM based on preserving Catholicism at a stage before its $20^{\text {th }}$ century evolution. As such, Mayer's work on the religious social movements helps situate TFP as an insurrection movement within Catholicism, specifically against the perceived progressivism of Vatican II and liberation theology. However, TFP is not the only traditionalist Catholic movement with pre-conciliar positions and Introvigne's analysis from a religious economy perspective on how different religious movements position themselves internally and with the externally explains TFP's evolution over time and its near schism with the Catholic hierarchy.

In addition to being a religious movement, TFP has equally been a politically active, trans-national social movement. Margaret Power (2010) explains the important role TFP played in the global fight against abortion and Communism from the 1960 s to the 1980s. Stephan Ruderer (2012) analysed TFP's role as a standard bearer for Catholic fundamentalism translating into a synergistic relationship with the authoritarian regimes of Pinochet's Chile and Videla's Argentina (Ruderer 2012). Finally, Peñas Defago's, et. al (2018) conceptualization of the modernisation of conservative social movements in the early $21^{\text {st }}$ century combined with Paternotte and Kuhar's (2017) analysis of anti-gender movements shed light on TFP affiliates' influence on SRR today.

On this basis, this article seeks to understand two phenomena: first, the development of TFP in Europe; and second, TFP's ability to organize and impact issues which are among its priorities, specifically SRR. This article does not explore the religious beliefs and practices within the TFP network.

\section{SPREAD, GROWTH AND DIVISION OF TFP}

Based on such powerful ideals and a charismatic leader, the TFP network grew to comprise over 40 organizations spread across several continents. The TFP network became what it is today over the course of four distinct phases: the first being from the foundation in 1960 to the early 1990s; the second precipitated by the fall of the Berlin Wall in 1989; the third precipitated by the founder's death in 1995 and finally the fourth from the conclusion of the legal challenges to the present. ${ }^{7}$ 
NEIL DATTA

MODERN-DAY CRUSADERS IN EUROPE. TRADITION, FAMILY AND PROPERTY: ANALYSIS OF A TRANSNATIONAL, ULTRA-CONSERVATIVE, CATHOLIC-INSPIRED INFLUENCE NETWORK

\subsection{The First Phase: FOUNDATION AND EXPANSION}

In 1968, the TFPs then existing in South America... organized national petition drives addressed to Paul VI, requesting measures against leftist infiltration into the Catholic clergy and laity of South America. Altogether, 2,060,368 people in Brazil, Argentina, Chile, and Uruguay signed the petition during a 58-day period. (Corrêa de Oliveira 1959, 97)

From its origins in Brazil in 1960, TFP then spreads first to other Latin American countries by founding local non-governmental organisations where the climate created by authoritarian military regimes provided fertile ground (Ruderer 2012). The founder and a close circle of confidants drawn from the other initial founders tightly controlled this expansion and the founder himself personally chose the names of the organizations in each country (Matta 2008). In the early 1970s, TFP appeared in France (Tfpfrance.org) where it settled in a château in the region of Lorraine ${ }^{8}$ from where it spread to other European countries. ${ }^{9}$ At the same time, outposts appeared in Canada, South Africa, the USA and Australia. ${ }^{10}$

In this period TFP's primary targets were Communism and Liberation theology, the two forces joining to promote agrarian reforms which threatened the interests of its land owning founding members. Margaret Power (2010) and Gonzalez Ruiz (2006) describe TFP's role in socially conservative movements in Latin America where TFP developed their signature public campaigns which combine displays of religious expression with political actions. An early attempt to root out liberal tendencies inside the Church took place in Chile, with the TFP affiliate Fiducia publishing a scathing criticism of the Chilean Catholic Church in $1976^{11}$ where it accused the Chilean Bishops of having acted in complicity with the leftist/Marxist Frei and Allende governments to carry out socialist reforms.

Similar pressure was exerted in Europe, for example in 1981 in France with an open letter about the ills of the Socialist government of François

8 Fédération Pro-Europa Christiana - Creutzwald (Fpec-creutzwald.org).

9 Deutsche Gesellschaft zum Schutz von Tradition, Familie und Privateigentum e.V. (Tfpdeutschland.de); L’Associazione Tradizione Famiglia Proprietà (Atfp.it); Acção Família (Accaofamilia.eu); Irish Society for Christian Civilisation (Isfcc.org); and Österreichische Gesellschaft zum Schutz von Tradition, Familie und Privateigentum (Tfp.at).

10 Canadian Society for the Defence of Christian Civilization (Canadaneedsourlady.org); The American Society for the Defense of Tradition, Family and Property (Tfp.org), South Africans for a Christian Civilization ceased functioning in the early 2ooos; and Australian Tradition, Family and Property (Tfp.org.au).

11 Fiducia, 1976. La Iglesia del Silencio en Chile - La TFP proclama la verdad entera. http:// www.pliniocorreadeoliveira.info/GestaES_0408_1976.htm\#.WIN_mExFxJU. 


\section{6 \\ POLITIČKE PERSPEKTIVE \\ ČLANCI I STUDIJE}

Mitterand entitled What Does Self-Managing Socialism Mean for Communism: A Barrier? Or a Bridgehead? (Corrêa de Oliveira 1981). The letter was published in leading newspapers around the world, while TFP asserts it was able to mail it to 300,00o people in France.${ }^{12}$ Building on this success, the Spanish TFP-Covadonga released España, anestesiada sin percibirlo, amordazada sin quererlo, extraviada sin saberlo - La obra del PSOE (TFP Covadonga 1988) in 1988 on how the Socialist government of Félipé Gonzalez had betrayed Spain.

In this first phase, TFP had become an influential, international, antiCommunist movement as well as a successful traditionalist insurrection within Catholicism. However, it also started encountering the first instances of the two main challenges which would haunt it for decades: hostility from the Catholic hierarchy and legal difficulties arising from TFP's alleged practices.

\subsection{The Second Phase:}

\section{RE-FOCUS IN A CHANGING ENVIRONMENT}

A number of external factors provoked the TFP network to shift focus, thus entering a second phase in its existence. These include the fall of the Berlin Wall (signalling the demise of its greatest foe, Communism), the Vatican's formal condemnation of liberation theology and the presence of a sufficiently conservative Pope. As Barker describes, a characteristic of NRM's is that "they are likely to change far more quickly and fundamentally than older, more traditional religions" and this is evidenced as TFP leaders worked to create new types of organizations focusing on social issues of the day, namely abortion and the related human rights on sexuality and reproduction. The anti-abortion organizations Droit de Naître in France and Generazione Voglio Vivere in Italy would appear in the early 1990s. This addition to the TFP template proved successful and spread to Germany, Austria and Poland. ${ }^{13}$ Another experiment was that of Luci sull'Est in Italy, which focused on bringing the TFP message to previously formally atheist Eastern Europe. A successful early example which still generates pride in the TFP network is the mass petition supporting Lithuanian independence in 1990 which gathered the support of over 5 million people, earning it a place in the Guinness Book of World Records (Corrêa de Oliveira 1991).

12 Ibid.

13 Aktion Kinder in Gefahr (KIG) (Aktion-kig.de); SOS Leben (Dvck-sosleben.de) and Prawo do Narodzin (Prawodonarodzin.pl). 


\subsection{The Third Phase: Legal Challenges}

At the movement's height, Corrêa de Oliveira passed away in 1995, marking the beginning of the third and most troubled phase in the movement's history which only ended in 2004. As often happens in movements built around the founder's charisma and where large-scale finances are at stake, internal strife broke out between different TFP factions. The factions emerged around three main differences: 1) the use of the TFP brand; 2) the future direction of TFP as a political campaigning organization; and 3) the religious teachings of the organization. This led to legal action with a series of decisions from the Brazilian courts in 1997 and 2004 (ISTOE 2013; Bezzera 2013).

The trial resulted in a victory (ISTOE 2013; Bezzera 2013) for the faction which wished to mend fences with the Church and downplay the organization's political engagement. External factors, including the presence of a conservative Pope, allowed the winners, led by a former lieutenant of Corrêa de Oliveira, ${ }^{14}$ to pursue a different path - that of rapprochement with the Vatican - by having the organization recognized as an International Association of Pontifical Right in 2001, known as the Heralds of the Gospel (Heraldsusa.org). The Heralds of the Gospel is thus the spiritual wing of the TFP movement, sharing many of the devotional traits of TFP as well as some of the visual branding in ceremonial clothing, but shedding the social and political activism which had characterized TFP's temporal dimension. Most importantly, TFP transitioned from a near schismatic insurrection to a fully integrated Catholic movement.

While the Heralds retained the rights to the TFP brand in Latin America and Iberia, it does not actively use it, leading to the TFP organisations in those regions to gradually disappear. The losing side in Brazil founded the Association of the Founders (Fundadores.org.br) and an online library dedicated to the founder's writings (Pliniocorreadeoliveira.info). However, the TFP organisations in Europe remained unaffected by the Brazilian verdict and continued their development, some growing to positions of influence in Eastern Europe, while the disappearance of TFP created space for a new socially conservative organisation to emerge in Spain.

\subsection{The Fourth Phase: Re-Birth in Europe}

A fourth phase emerged in the early $21^{\text {st }}$ century with a less centralized leadership, allowing for innovation. Most importantly, the centre of the movement would shift from Brazil to Europe, first to France and later to 
 \\ POLITIČKE PERSPEKTIVE \\ ČLANCI I STUDIJE}

Poland. From its French headquarters, TFP bought a building in Brussels in 2008 and opened a representation to the European Union under the name Fédération Pro-Europa Christiana (FPEC) (Fpec-bxl.be) and in 2011, its own academy at its Lorraine headquarters, the Institut Européen de Sciences Sociales (IESS) (Sciencessociales.fr). The TFP network developed rather quickly, with a flourishing infrastructure appearing in Austria ${ }^{15}$ and Germany $^{16}$ and Italy. ${ }^{17}$

The most recent TFP innovation has been to expand into litigation and policy development with the creation of Ordo Iuris in Poland in 2001. Ordo Iuris is the first experiment in developing legal and policy expertise which has been active in 'law-fare ${ }^{18}$ processes before the Polish courts and European Institutions. ${ }^{19}$ The Polish TFP organisations seem to have taken the leadership within the movement as they have expanded the franchise to Croatia ${ }^{20}$, Estonia ${ }^{21}$, The Netherlands ${ }^{22}$, Slovakia ${ }^{23}$ and Switzerland. ${ }^{24}$ This new generation of TFP organisation takes to a higher level what had been signature TFP methodologies (see section 5) corresponding to the professionalization of conservative actors (Peñas Defago, et. al. 2018). These new TFP organisations have become key actors, at times

15 Österreichische Gesellschaft zum Schutz von Tradition, Familie und Privateigentum (Tfp.at)

16 Der Adel (Der-adel.info); Deutschland braucht Mariens Hilfe (Mariens-hilfe.de); and Deutsche Gesellschaft zum Schutz von Tradition, Familie und Privateigentum e.V. (Tfpdeutschland.de); Deutsche Vereinigung für eine christliche Kultur (Dvck.de) and https:// kultur-und-medien-online.blogspot.com/2011/03/deutsche-vereinigung-fur-eine.html.

17 Associazione Tradizione, Famiglia, Proprietà (Atfp.it); Centro Studi Storici sulla ControRivoluzione (CESCOR, Cescor.org); Corrispondenza Romana (Corrispondenzaromana.it); La Famiglia Domani (Famigliadomani.it); and the Lepanto Foundation (Fondazionelepanto. org).

18 "Lawfare" includes legal mobilization and litigation at national and international level (Yamin, Datta and Andion, 2018).

19 For examples of 'lawfare', see: http://www.ordoiuris.pl/interwencje-prawne, as of 10 March 2019.

2o Centar za obnovu culture (Cok.hr); Vigilare (Vigilare.org); and TradFest (Tradfest. org).

21 Sihtasutus Perekonna ja Moraaliseaduse Kaitseks (Association for the Defence of Family and Morality (Saptk.ee)); Elukultuuri Instituut (The Institute for Life Sciences): https:// elukultuur.wordpress.com; Objektiiv.ee (SAPTK's news and opinion portal) and Abort.ee, as of 10 March 2019.

22 Stichting Civitas Christiana ('Cultuur onder Vuur' (Cultuurondervuur.nu)); Stirezo (Stichting Recht Zonder Onderscheid) Pro-Life (Stirezo.nl); and Gezin in Gevaar (Geziningevaar.nl).

23 Nadácia Slovakia Christiana (Slovakiachristiana.sk); Fatima Slovensko (Fatimapreslovensko.sk)

24 Helvetia Christiana (Helvetia-christiana.ch) 
leaders, in the anti-gender campaigns in Europe which Kuhar and Paternotte (2017) describe.

\subsection{The Case of Spain}

An interesting case is that of Spain. For nearly three decades, a successful TFP organization thrived in Spain, the TFP-Sociedad Cultural Covadonga. ${ }^{25}$ TFP-Covadonga was a victim of the court case in Brazil and disappeared around 1999. However, in 2003 a new organization called Hazte Oir appeared which seems to fit many of the characteristics often associated with TFP (see section 5), including: grass-roots mobilization combined with fundraising, multiplicity of branding, youth outreach, the same US contacts, intense contact with other TFP organizations and, finally, exercising traditionalist pressure on the Catholic Church. It diverges from TFP characteristics primarily in its branding, and, while Catholic inspired, Hazte Oir is by no means a religious movement, and there are no references to Corrêa de Oliveira. Hazte Oir (literally, 'make yourself heard') plays a watchdog role on Spanish political life and launched a social mobilization platform "CitizenGO" which would appear to be a $21^{\text {st }}$ century digital version of the direct mailing techniques TFP pioneered in the 1970 s (see section 8). Hazte Oir may be the reincarnation of TFP-Covadonga under a new set of circumstances where there are limits as to how openly it may display its affiliations in Spain ${ }^{26}$ (see section 6). Whether Hazte Oir is formally part of the TFP family or not, it shares many of the characteristics of TFP organizations and occupies the same niche.

\subsection{TFP REACH}

Taken together, TFP organizations exhibit diversity in size, reach and funding. The TFP umbrella organization, the FPEC, declares an average annual turnover of approximately $€ 2$ million to French authorities, ${ }^{27}$ originating from the membership fees across Europe. These member organisations in turn generate this revenue through their fundraising initiatives.

25 For TFP's presence in Spain, see: http://www.pliniocorreadeoliveira.info/GestaES_ o211Espana.htm\#.WVIL7oVOKUk.

26 Agente Provocador. 2017. "Los «caballeros medievales» de Covadonga son peores que Hazte Oír." Agente Provocador, 8 March. http://www.agenteprovocador.es/publicaciones/ hazte-oir-poda-ser-peor.

27 FPEC's 2012 and 2017 annual accounts: Association Pro Europa Christiana. 2012. Rapport au Commissaire des Comptes sur les comptes annuels, exercice clos le zo juin 2012 and FPEC's 2017 annual accounts: Association Pro Europa Christiana. 2017. Rapport au Commissaire des Comptes sur les comptes annuels, exercice clos le 30 juin 2017. Creutzwald: FPEC. 
POLITIČKE PERSPEKTIVE

ČLANCI I STUDIJE

FPEC also owns several real estate properties in France and in Brussels. ${ }^{28}$ However, other TFP affiliates are more modest; some may not even be registered officially and are only informal associations of individuals with a light web presence. ${ }^{29}$ TFP individual members are not likely to number more than a few hundred individuals per country and have traditionally been all-male..$^{30}$ However, their small size in personal affiliation is compensated for by their public outreach, which can reach several hundreds of thousands of people, depending on the country.

From these small number of adherents, TFP leverages influence in two ways: first, by attracting 'elites' with a specific background. The place of honour reserved for aristocrats attracted a number of noble families to become supporters - for example, the TFP representative to the EU is Paul, Duke of Oldenburg ${ }^{31}$ (a grandson of the last German Emperor), or the late Luigi, Marquis of Naples, who is described as "a personal friend of Prof. Plinio Corrêa de Oliveira's” (Nobility.org 2015). Specifically, TFP favours a return to power of the former Brazilian imperial family, the family of Orléans-Bragança, who feature prominently at TFP events. ${ }^{32}$ Indeed, TFP is the clerico-aristocratic network par excellence which Kemper describes ${ }^{33}$ in the landscape of anti-gender actors. Second, the mainstay of the TFP leadership in Europe to this day are Latin American men and returnee émigrés who took Corrêa de Oliveira's message from its native Brazil and spread it across the Europe. ${ }^{34}$

28 These properties are La Villa Clairière in Creutzwald, the Le Jaglu château in Châteauneuf-en-Thymerais and a townhouse on rue Taciturne in Brussels.

29 TFP Malta https://www.facebook.com/pg/ProMaltaChristiana/about/ retrieved 17 March 2019

30 Introvigne (2009) and Assemblée nationale. 1995. Rapport fait au nom de la Commission d'enquête sur les sectes, Rapporteur M. Jacques Guyard, 20 décembre 1995. Paris: Assemblée Nationale which categorized the French TFP organizations among those with between 50 and 500 members.

31 FPEC (Fpec-bxl.be) and European Parliament Transparency Register entry on FPEC as of 19 March 2017: http://ec.europa.eu/transparencyregister/public/consultation/displaylobbyist.do?id=65395896737-91

32 See the programmes of Summer Academies and Chivalry Camps listed above.

33 Kemper, Andreas. 2015. "Christlicher Fundamentalismus und neoliberal-nationalkonservative Ideologie am Beispiel der 'Alternative für Deutschland'. In "Unheilige Allianz Das Geflecht von christlichen Fundamentalisten und politisch Rechten am Beispiel des Widerstands gegen den Bildungsplan in Baden-Württemberg Ideologie am Beispiel der 'Alternative für Deutschland"', edited by Lucie Billmann, Rosa Luxembourg Stiftung.

34 Among the Latin American men are Caius Vidigal Xavier da Silva, Nelson Fraginelli and José Ureta. Examples of returnee émigrés include Matthias von Gersdoff (born in Chile and founding the German TFP), Carlos Eduardo Schaffer (born in Brazil and founding the Austrian TFP) and Leonardo Prybysz (born in Brazil and founding the Polish TFP). 


\section{SHARED TFP TRAits}

Gizele Zanotto (2007) characterises TFP as a 'chameleon' being able to take on different shapes and colours to suit its changing surroundings. However, the TFP chameleon comes only in a limited range of shapes which are recognizable as: 1) TFP organizations; 2) cultural organizations;35 3) anti-abortion organizations; ${ }^{36} 4$ ) organizations dedicated to Mary or Fatima; ${ }^{37}$ and 5) legal organizations named Ordo Iuris. ${ }^{38}$ The fact that they are part of the TFP network is evidenced by their mutually referencing each other as part of the same network; that the same individuals involved in TFP organizations are also involved in these other organizations; and their use of TFP branding. Despite their brand multiplicity, key traits of TFP affiliates include: shared leadership; iconography and branding; youth outreach; fundraising techniques; transnational links outside the TFP family; a specific focus for religious veneration; and links with far-right movements.

TFP organizations share the same leadership which tend to be led by a small cadre of men, usually of Latin American origin as well as European aristocrats. These men exchange roles in different TFP-related organizations, for example, one individual will be president of organization $\mathrm{X}$, board member of organization Y and a staff member of organization $\mathrm{Z}$. This is done within countries and transnationally. In short, the leadership of the many TFP-associated organizations around the world is held by a small and interchangeable cadre of men. ${ }^{39}$

Another common feature is TFP's unique iconography, drawing on a medieval crusader motif. Aside from the 'lion rampant' visual for some TFP organizations' logos, others which do not bear the TFP name do make use

35 Fédération Pro-Europa Christiana (Federation-pro-europa-christiana.org); and for France: Avenir de la Culture (Avenirdelaculture.org); and for Germany: Deutsche Vereinigung für eine christliche Kultur (Dvck.de).

36 See for France Droit de Naître (Droitdenaitre.org); for Italy Generazione Voglio Vivere (Generazionevogliovivere.it); for Poland Prawo do Narodzin (prawodonarodzin.pl)

37 South Africa Needs Our Lady (Sanol.co.za); and America needs Fatima (Americaneedsfatima.org).

38 See for Poland Ordo Iuris - Instytut na Rzecz Kultury Prawnej (Ordoiuris.pl)

39 For example, Nelson Fraginelli is involved in the TFP organizations in Brazil, France, Italy and the USA; Paul, Duke of Oldenburg, heads the TFP office in Brussels and is on the boards of the TFP organizations in Canada and Estonia. Also on the board of the Estonian TFP is Stawomir Olejniczak, who is on the Polish and Croatian TFP's boards. Valdis Grinsteins serves on the Estonian and US TFP's boards. The Canadian TFP board assembles individuals from TFP organizations from across the world, such as Georges Martin from the French TFP affiliate, Jose Antonio Ureta from the Chilean TFP member, who also helped establish the South African TFP, and Carlos Eduardo Schaffer, who was also active in TFP Brazil and a founder of the Austrian TFP. 
POLITIČKE PERSPEKTIVE

ČLANCI I STUDIJE

of the logo - for example, Vigilare in Croatia and Ordo Iuris in Poland..$^{40}$ In addition, the Crusader motif is regularly used by TFP affiliates, ${ }^{41}$ and the founder himself is styled as a crusader. ${ }^{42}$ Related to this is the use of historical personalities or important Christian victories in the names of TFP organizations. ${ }^{43}$ A number of TFP events are in fact celebrations of medieval imagery, such as TradFest, "a festival of tradition and conservative ideas", which takes place in Croatia since 2016.44

The medieval imagery infuses TFP work in another area: that of youth outreach. Several TFP organizations run summer schools for young people, mainly adolescent boys and young men. TFP affiliates call the youth camps Summer Academies in Austria, Germany and Poland and Chivalry Camps in Ireland and the USA.45 TFP characteristics are on display at these youth camps - for example, the medieval imagery, complete with "parades of manly chivalry", the involvement of aristocrats and readings from the works of the founder and TFP religious ceremonies. ${ }^{46}$ This has most recently coalesced into creating TFP Student Action Europe in 2017 which mobilizes these same young men into street protests. ${ }^{47}$ While the youth activities target adolescent boys and young men, the TFP network expanded to post-secondary education by opening the Institute d'Etudes sur les Sciences Sociales (IESS). The IESS faculty and board are composed of the same personalities who make up the leadership of TFP organizations, as well as their wives. ${ }^{48}$ The courses the IESS offers are aimed at

40 Vigilare displays the TFP lion on Facebook (https://www.facebook.com/Vigilare) but not its website (Vigilare.org), and Ordo Iuris displays the TFP lion's head (Ordoiuris.pl).

41 Krucjata Młodych (Youth Crusade) in Poland (Krucjata.org.pl).

42 de Mattei, Roberto. 1996. El Cruzado del Siglo XX. Asociación Tradición y Acción por un Perú Mayor.

43 For example, Piotr Skarga, from which the Polish TFP organization takes its name, was a famous 16th century Polish Jesuit who was active in the Counter-Reformation by being critical of religious tolerance and advocating for monarchical powers.

44 Tradfest (Tradfest.org).

45 For Summer Academies in Europe, see http://tfp.at/2007/o7/31/lernen-um-den-stuermender-geschichte-zu-trotzen-sommerakademie-2007 and http://tfp-france.org/285or/universitedete-2017-des-tfp-en-europe, for the Summer University of TFP in Niepołomice, Poland see https://www.youtube.com/watch?v=gPf6eKfmfZs and https://www.youtube.com/watch?v=VlQpL5h99s); and for Chivalry Camps in Ireland, see https://www.isfcc.org/summer-camps and https://www.youtube.com/watch?v=PBDIuJa5LcI\&feature=autoshare; and https://www.tfpstudentaction.org/get-involved/call-to-chivalry-camps/tfp-chivalry-camp-in-the-shadow-ofthe-sequoias in the USA, as of 10 March 2019.

46 See the programmes of Summer Academies and Chivalry Camps listed above.

47 https://tfpstudentactioneurope.org/ as of 11 March 2019.

48 http://www.sciencessociales.fr, where Edyta Olejniczak, the spouse of Stawomir Olejniczak (Polish and Croatian TFP), as well as Catherine Rochet-Goyard, the spouse of Jean Goyard (French TFP), Maria Del Pilar, Duchess of Oldenburg, the spouse of Paul, Duke 
'leading a profound reflection on European culture with an emphasis on its Christian roots and thus responding to Pope Jean Paul II's call for an evangelization of culture. 49

Despite its elite origins and governance, TFP organizations specialize in grass-roots mobilization. TFP organizations excel at mass mailings, public campaigns and protests (see section 8.1). A number have even developed their own media ranging from magazines/reviews to news agencies and even television channels..$^{5}$ This grass-roots outreach helps them in another area: fundraising. TFP's fundraising toolkit includes requesting funds for campaigns; often several campaigns take place at the same time. Carlos Eduardo Schaffer, who was involved in several TFP organizations, is credited with having developed the system of direct mail and fundraising for the organization through personal visits .... [and] is now developing a system of fundraising through mass e-mails in combination with a call center..$^{51}$ The TFP model of direct mail fundraising was described by a French inter-ministerial body in 2006 (MIVILUDES 2006) as comprising four distinct phases: 1) prospecting potential donors; 2) direct mailing to their homes; 3 ) sharing a database of contacts with other organizations within the TFP network; and 4) home visits to request regular, monthly contributions. This 2006 report notes that the fundraising campaigns are often an end in themselves, as no funds collected will be spent to address the issue identified, except to fundraise for the campaign itself (Ibid).

Another characteristic which TFP affiliates share is their transnational partnership with an actor in the USA, the Leadership Institute (LI)..$^{2}$ The LI describes itself as teaching conservatives of all ages how to succeed in politics, government, and the media. ${ }^{53}$ Gordon Blackwell, an influential voice of the US Christian Right and founder of the LI, praises TFP, stating ... Intensely Catholic, their members receive Communion every day. Although a secular group, in some ways they could be likened to a medieval religious order. They stand opposed to much that has occurred in modern times, which they consider to have commenced at the end of the Middle Ages, a not unreasonable view. They intend to save Western civilization or to die

of Oldenburg (FPEC), Mme Heleen Bos-Boerefyn, the spouse of Hugo Bos (Dutch TFP) are listed as faculty and board members, as of 10 March 2019.

49 From http://www.sciencessociales.fr/institut/cours.

50 Correspondance européenne (Correspondanceeuropeenne.eu); Corrispondenza Romana (Corrispondenzaromana.it); Polonia Cristiana24 (Pch24.pl); of the Estonian SATPK (Objektiiv.ee)and Radici Cristiane (Radicicristiane.it) (access 10. 3. 2019).

51 See biography as of 1o March 2019: https://leadershipinstitute.org/training/contact.cf $\mathrm{m}$ ?FacultyID=679589\#sthash.hLTOnqij.dpuf.

52 Leadershipinstitute.org..

53 https://www.leadershipinstitute.org/aboutus. 
POLITIČKE PERSPEKTIVE

ČLANCI I STUDIJE

trying. Since my visit to Brazil, I have taken opportunities to meet national TFP leaders in my travels to half a dozen countries on four continents (Blackwell 2010). TFP organizations and LI collaborate on a range of training events in Europe, with workshops focusing on fundraising, lobbying and advocacy. ${ }^{54} \mathrm{~A}$ deeper relationship exists whereby the leadership of TFP organizations (the same cadre of men mentioned above) are also visiting professors for the LI. ${ }^{55}$

TFP is also a religious movement and as such focuses on certain aspects of the Catholic religion - specifically, the veneration of the Virgin Mary and secrets of Fatima ${ }^{56}$ which play prominent roles in TFP public and private ceremonies. Dedicated websites to Fatima operated by TFP exist in nearly all countries where TFP has a presence. ${ }^{57}$ TFP combines its religious devotion with its fundraising outreach by selling the books written by the founder ${ }^{58}$ and religious items, such as a 'miraculous medal' featuring a Catholic motif.59

A final characteristic of the TFP movement is its proximity to elements of the far-right, specifically of the older fascist traditions in Europe and Latin America. TFP affiliates in France are close to fascist political parties (Compagnon, 2008), with the Italian TFP members described as being "parts of a galaxy of traditionalist and Far-Right movements". ${ }^{60}$ Conversely, TFP activities attract persons involved in far-right parties, for example

54 Leadership Institute training programmes for Madrid (2009) and London (2010, 2011).

55 TFP personalities referred to as having a function at LI:

Carlos Eduardo Schaffer: https://leadershipinstitute.org/training/contact.cfm? FacultylD=679589;

José Ureta: http://www.leadershipinstitute.org/Training/contact.cfm?FacultyID=144665;

Silvio Dalla Valle: https://www.leadershipinstitute.org/training/contact.cfm? FacultyID=144662;

Sławomir Olejniczak: http://www.leadershipinstitute.org/Training/contact.cfm?Faculty ID=139901; and Matthias von Gersdorff: https://www.leadershipinstitute.org/training/contact. cfm?FacultyID=144668, as of 10 March 2019.

56 Bertone, Tarcisio, SDB, Archbishop Emeritus of Vercelli, Secretary of the Congregation for the Doctrine of the Faith. 20oo. "Congregation for the Doctrine of the Faith: The Message of Fatima." La Santa Sede website: http://www.vatican.va/roman_curia/congregations/cfaith/ documents/rc_con_cfaith_doc_200oo626_message-fatima_en.html.

57 Examples include in Austria (Fatimaonline.at); Canada (Canadaneedsourlady.org); Germany (Mariens-hilfe.de and Fatima-familie.de); Peru (Fatima.org.pe); Poland (Przymierzezmaryja.pl); South Africa (Sanol.co.za); and the USA (Americaneedsfatima.org). (Access 10.1.2019).

58 To purchase the works of TFP, see: http://store.tfp.org/ and http://www.ksiegarnia.poloniachristiana.pl/, as of 10 March 2019.

59 http://www.die-wundertaetige-medaille.de; and http://medaglia-miracolosa.it (access 10. 3. 2019).

6o Garbagnoli, Sara. 2017. "Italy as a lighthouse; Anti-gender protests between the 'anthropological question' and national identity." In Anti-Gender Campaigns in Europe, edited by 
the rising star of the Belgian Vlams Belang who participated in the TFP summer academy in Poland (Cochez 2019). In some cases, the relations between TFP leaders and fascism are personal (Piątek 2017c). In Spain, the TFP-Covadonga was historically close to the Franco regime, ${ }^{61}$ and in Latin America, national TFP affiliates maintained close links with the various military dictatorships from the 1970 onwards Ruderer 2012). The relationship was mutually reinforcing, with TFP providing a moral 'truth' for the exercise of power by such forces. Ruderer (2012) explains all these are concepts that dictatorships used to legitimize violence, were found in the texts of the TFP already in the 6os (translated from Spanish N.D.). ${ }^{62}$

\section{Relations with the Catholic Church}

TFP's relationship with the Catholic Church needs to be situated within the context of the emergence of various streams of $20^{\text {th }}$ century Catholic thinking and movements. Compagnon (2008) recalls how there were three broad movements within the Catholic world starting in the late $1950 \mathrm{os}$. The first was the liberation theology which advocated for a Catholicism better adapted to the developing world by addressing inequalities. The second Christian democracy, which sought to bring the social doctrine of the Church into politics, resulting in a number of Christian Democratic parties across Europe and Latin America. The third current was that of Catholic fundamentalism, of which the Brazilian TFP was among the first representatives. (Compagnon 2008)

TFP was founded at a time when the Church was undergoing great turmoil with various competing currents pulling in different directions. The founder is reported to have attended the Second Vatican Council but left early, as he was unhappy with the liberal, progressive wind sweeping the delegates. ${ }^{63}$ For Corrêa de Oliveira, there were two great enemies he must confront: Communism was the primary external enemy, while liberation theology was the main enemy within. As such, TFP is what Mayer (1982) in his political-economy approach to religious movements, would refer to as an insurrection within Catholicism, at times bordering on a schism. As Mayer explained, such insurrection movements understand their relative autonomy/vulnerability towards the official hierarchy and which explains why TFP entities are not constituted as Catholic entities;

Roman Kuhar and David Paternotte, Chapter 9. Lanham, MD: Rowman and Littlefield International.

61 Agente Provocador. 2017.

62 Ibid.

63 See biography at http://www.traditioninaction.org/Collection/Bios/Eoo1_Bio_SDP. html. 
POLITIČKE PERSPEKTIVE

ČLANCI I STUDIJE

rather, they are legally constituted as civil organizations according to the laws of the countries where they are based (Matta, 2008).

A serious degradation of relations occurred in the 1980 s when National Conference of Bishops of Brazil (NCBB) accused TFP of straying away from the teachings of the Church. In 1985, the NCBB wrote a letter decrying TFP's alleged apostasy - namely, Its esoteric character, the religious fanaticism, the cult given to the personality of its leader and his mother, the abusive use of the name of Mary Most Holy, according to news items circulated, cannot in any way merit the approval of the Church. ${ }^{64}$ As a result, Corrêa de Oliveira's TFP was explicitly disavowed by the bishops. (Introvigne 2009) Because of this, some even questioned TFP's authenticity as a Catholic movement, instead dubbing it 'pseudo-Catholic'. ${ }^{65}$ Critics also came from within. Orlando Fedeli, one of the founding members of TFP, described the movement as having degenerated into a 'burlesque gnosis' (Fedeli 2010). At one point, Oliveira had gone down, with these criticisms, a path openly schismatic, of separation from the Church. (Cariello 2008)

Since the death of the founder and the courts in Brazil issued their verdict, relations between the TFP family and the Catholic Church have improved. The religious wing of TFP is now its own International Association of Pontifical Right known as the Heralds of the Gospel. As the religious aspects of TFP went with the Heralds, the more eccentric devotional ceremonies of the past no longer posed an obstacle. This resulted in greater but not complete acceptance of TFP organizations within the wider world of Catholic laity until recently. (Introvigne 2009) At the same time, under Pope Benedict, the Church was sufficiently conservative so as to no longer warrant an internal insurrection.

However, the arrival of Pope Frances, often seen as a liberal and moderniser, has awoken the need for conservative pressure. Thus, TFP attempted to exert pressure to prevent reforms with its Declaration of Fidelity to the Church's Unchangeable Teachings on Marriage and to her Uninterrupted Discipline, ${ }^{66}$ signed by many TFP members as well as the aristocrats the network attracts in advance of the Extraordinary Synod on the Family in 2015. ${ }^{67}$ Similarly, in 2017, a group including Roberto De Mattei of the Italian TFP signed A Filial Correction Concerning the Propagation of Heresies, also

64 TFP. 2007. “The American TFP's 2007 comments regarding a note on the Brazilian TFP approved by the National Conference of Bishops of Brazil on April 19, 1985." TFP website. http://www.tfp.org/ref/ncbb.pdf.

65 Assemblée nationale. 1995. Rapport fait au nom de la Commission d'enquête sur les sectes, Rapporteur M. Jacques Guyard, 20 décembre 1995. Paris: Assemblée nationale.

66 http://filialappeal.org.

67 http://www.vatican.va/roman_curia/synod/documents/rc_synod_doc_20151026_ relazione-finale-xiv-assemblea_en.html. 
known as a Dubia (the 25-page letter was delivered to the Pope), ${ }^{68}$ to Pope Francis's Amoris Laetitia ${ }^{69}$ (a post-synodal apostolic exhortation addressing the pastoral care of families). TFP's positioning within the Church is thus delicate from the start: TFP is loyal to the Vatican but exerts conservative pressure on it and is allied to some of the more conservative elements in the Church hierarchy, particularly at times when the leadership is seen as progressive.

Massimo Introvigne (2009) ${ }^{70}$ analyses TFP and the Heralds of the Gospel from the perspective of religious economy. Recalling religious economic theory, where a market for religion exists and there may be competition both inter-brand (different religions) and intra-brand (different movements within a same religion) for religious consumers, Introvigne explains how TFP catered to the 'strict' or 'ultra-strict' Catholic religious market from the movement's founding until the founder's passing. TFP and, later, the Heralds of the Gospel would appear to have shifted towards the 'strict' (for TFP) to 'moderate conservative' (for the Heralds of the Gospel) markets for a number of reasons, among them intra-brand competition with the SSPX and because the potential markets for the 'strict' to 'moderate conservative' religious consumers are far larger than the 'ultra-strict' market. Introvigne also explains why organizations emanating from the TFP movement display their proximity to the movement differently: "The fact that the Heralds of the Gospel, whose leadership is largely composed of former prominent TFP members, downplay their relationship with Corrêa de Oliveira allows a number of Brazilian bishops to support them without either revisiting the history of the NCBB." (Introvigne 2009, 7). The ambiguity in how openly TFP organizations associate with the TFP brand is thus a defining feature of the network.

68 http://www.ncregister.com/blog/edward-pentin/group-of-clergy-and-laity-issue-filialcorrection-of-pope-francis.

69 https://w2.vatican.va/content/dam/francesco/pdf/apost_exhortations/documents/ papa-francesco_esortazione-ap_20160319_amoris-laetitia_en.pdf.

70 Massimo Introvigne is involved in several TFP-related organizations, including the Italian Alleanza Cattolica (https://berkleycenter.georgetown.edu/people/massimo-introvigne), and founder of the Centre Studi Storici sulla Contro-Rivoluzione (CESCOR: Cescor. org) dedicated to the writings of Plinio Côrrea de Oliveira. Introvigne is also the founder of the Centre for the Study of New Religions (CESNUR), which is regarded as a 'cult apologist' (http://www.apologeticsindex.org/c1o.html). 
POLITIČKE PERSPEKTIVE

ČLANCI I STUDIJE

\section{TFP CULT ACCUSATIONS AND LEGAL TROUBLES}

From the afterlife, Plinio Correa de Oliveira, while sitting next to the Virgin Mary in the sky, is also regulating climate change and working in favor of Pope Francis' imminent death. (Fsspx.news 2017)

No understanding of the TFP network is complete without also becoming familiar with its history of legal troubles and accusations it faced. The accusations against TFP fall into three categories: 1) indoctrination of children; 2) political extremism and 3) cult allegations.

\subsection{INDOCTRINATION OF CHILDREN}

TFP organizations' focus on youth has taken various forms, including summer camps as well as permanent educational institutions. Early in its history, in 1977, TFP organizations established a school in France. Following several complaints, the French Catholic Church investigated the complaints (La Depèche. 2003) which resulted in closing the school in 1979 when authorities concluded that the school served as a centre for recruitment and indoctrination. Indeed, the tribunal which judged the case stated the management of the establishment, almost all Brazilian nationals, exerted psychological pressure on the young people inciting them to... become adepts of a certain foreign organisation... (Leroy 1980). In return, the French TFP organizations launched a vigorous defence of their movement in 1980 (TFP-France 1980).

A few years later, in Venezuela, family members of young people involved in the local TFP organization filed a complaint with authorities, claiming that the organization created a conflict between parents and children, with the subsequent removal of the child or children (minors or adults) from their respective homes... that the aforementioned family conflicts have their cause or are induced through mental control techniques... whose ideology is related to the Brazilian Society of Defense of the Tradition, Family and Property (Venezuela Ministerio Público 1984). These allegations resulted in a police raid on the offices of Resistencia in October 1984 as well as a parliamentary investigation, generating wide media coverage. ${ }^{71}$ The result was the expulsion of the organization when the Ministry for the Interior and Justice considered that TFP's activities were contrary to the Constitution (Calcano de Temeltas 1999) and "once it was proven that the 
organization offended family values by instilling discriminatory values, turning youths into fanatics" (Cesnur.org. 2001)

\subsection{Political EXTREMism}

During the investigation in Venezuela a number of concerns arose regarding TFP related to the use of violence. Among the most serious concerns were that TFP devotees were allegedly involved in a plot to assassinate the Pope in 1984 while on a Pontifical visit to Venezuela which reportedly contributed to the expulsion of the TFP order from the country (Navarro 2004). However, in April 1984, the Chilean TFP member organization itself reports having been the victim of an attempted bombing of its headquarters in Santiago. ${ }^{72}$ Without delving into the credibility of these allegations, the Immigration and Refugee Board of Canada did list TFP as a 'religious para-military group' in 1998 (Immigration and Refugee Board of Canada. 1998), while TFP is classified as 'TFP and other violent groups' in the work of Gonzalez Ruiz on the far-right Mexican youth movement MURO (see next paragraphs for more on MURO). ${ }^{73}$

More recently, starting in 2011 and persisting today, the Spanish organization Hazte Oir has been the subject of a range of different accusations that it is the Spanish front of a far-right, ultra-Catholic, para-military, secret society from Mexico called El Yunque ('the Anvil') (El Plural. 2017; Mata 2015). Victoria Uroz Martínez, the wife of one of the alleged leaders of El Yunque in Spain, in an extensive interview in January 2015, describes her experiences of El Yunque and states that El Yunque uses TFP as a base to reach other countries. ${ }^{74}$ To understand the links between the TFP network and El Yunque, it is necessary to delve into the history of far-right movements in Latin America. Irene Ortiz (2008) explains how a violent, far-right youth group in Mexico, the Movimiento Universitario de Renovadora Orientación (MURO), which emerged in the 196os was a key contributing ingredient in what became El Yunque (Ortiz 2008). Separately, Gonzalez Ruiz (2006) explains how the Brazilian TFP maintained links with Mexican far-right groups, including MURO, in the 1970s. The allegations that Hazte Oir is linked with El Yunque reached mainstream media and prompted the head of Hazte Oir to file a lawsuit for defama-

72 Catolicismo. 1984. "Atentado contra sede da TFP chilena." Catolicismo 34(40o), April, page 12. http://www.pliniocorreadeoliveira.info/GES_19840314_Chileatentadoasede.htm.

73 Gonzalez Ruiz, Édgar. undated. MURO (Movimiento Universitario de Renovadora Orientación) Memorias y Testimonios 1961-2002. Puebla: Benemérita Universidad Autónoma de Puebla.

74 Jimenez Jacinto, Juan Francisco. 2015. “Entrevista a Victoria Uroz." Forum Libertas, 9 January. 
tion. In 2014, Hazte Oir lost the lawsuit, with the judge affirming that the allegations were "essentially true" (Jimenez/Juan 2015), resulting in some Spanish Catholic Bishops prohibiting Hazte Oir use of their facilities in 2015 (Bastante 2015).

Finally, TFP is also the subject of fanciful conspiracy theories, chief among them from US fringe politician from the 1980 and 1990s, Lyndon LaRouche, ${ }^{75}$ who accused the TFP of being the nexus of a vast network of aristocrats who were plotting to take over the world and assassinate his wife. ${ }^{76}$

\subsection{Cult allegations}

There have been persistent allegations directed at TFP that it is a 'cult' centring around two main concerns; on the one hand, there is suspicion from public authorities regarding possible harm to TFP members and the public at large and, on the other, accusations from ecclesiastical authorities about TFP's alleged doctrinal deviations.

Authorities in France were among the most proactive in investigating the former. In 1995 and 1999, the French National Assembly (Assemblée nationale. 1995) listed French TFP members among its list of cult-like movements, as did a public body in charge of monitoring cult activities in 2006.77 The 2006 report to the Prime Minister's office by the 'Interministerial mission for vigilance and fight against cult-like movements' describes the TFP affiliates as dedicated to fundraising for unspecified objectives $^{78}$ and having characteristics which are considered warning bells for cult-like behaviour, such as: increasing demands on persons involved in the campaigns; opacity of the hierarchy and structure; a high degree of hierarchy and the involvement of only a few key persons in the management; and distortion between the stated aims of a campaign and the eventual use of funds. ${ }^{79}$

From ecclesiastical authorities, in addition to the formal accusations of the NBCC of 1985 (see section 6), new accusations emerged in June 2017 of cult-like worship of Dr. Plinio and his mother, Lucilia. The leader

75 For more about Lyndon LaRouche, see Severo (2019).

76 EIR. 1985. "For an international mobilization to stop the TFP brainwashing cult." EIR 12(5), 5 February.

77 MIVILUDE (2006) and Tribunal Correctionnel de Chartres. 2001. "Tradition, Famille et Propriété, Avenir de la culture, Groupe inscrit sur la liste des sectes du rapport parlementaire de 1995, Procès 'Européenne de medias' (GEIE) contre 'L’Echo républicain de Chartres'” Echo communication, Audience of 17 September 2001.

78 MIVILUDES. 2006. page 93.

79 Ibid., page 3 . 


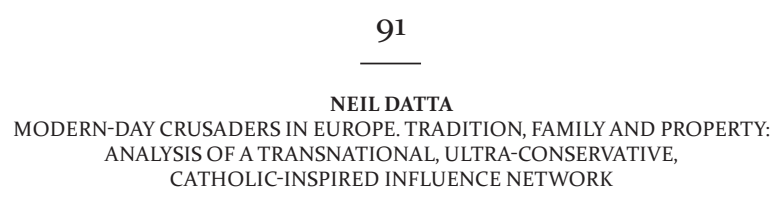

of the Heralds of the Gospel (see section 4.3) was placed under investigation by the Holy See's Congregation for Institutes of Consecrated Life in June 2017, when a series of videos featured him conducting religious ceremonies dedicated to Dr. Plinio and his mother and claiming that "climate change, and the increase of heat. It is Plinio who does everything." ${ }^{80}$ They are also under investigation for asserting that the current Pope is under the control of the devil and that he would soon die, as well as for using nonVatican-approved methods of exorcism. (Palmer 2017)

At a more personal level, blogs abound of ex-TFP and Heralds of the Gospel followers claiming to have escaped from the grips of what, according to them, is a cult-like movement. ${ }^{81}$ However, in 2008 the French government clarified that TFP has never been the subject of judicial proceedings and cannot be described as sectarian aberrations constituting acts liable to be penalized, ${ }^{82}$ while the Vatican investigation into the Heralds of the Gospel was still ongoing in 2019.

\section{TFP'S INFLUENCE ON SRR IN EUROPE TODAY}

Even though TFP has not often been recognised in Europe, it plays a leading role among the anti-gender landscape of movements and organisations (Kuhar and Paternotte 2017) and the anti-SRR advocacy networks such as Agenda Europe (Datta 2018). TFP's influence on SRR takes three main routes: social mobilization; norm entrepreneur; and infiltrating decision-making spaces.

\subsection{Social MOBILIZATION}

TFP social mobilization campaigns always have multiple targets: aiming at the general public, the political classes and the Catholic Church to maintain a socially conservative line, as well as other Catholics to rally them to TFP ideals and, when possible, also serve a fundraising objective. A recent example is a rosary reading and prayer event to mark the centenary of the miracle of Fatima and expiation of the sins of abortion, same-sex marriage and euthanasia in Belgium in front of the Palace of Justice in Brussels in October $2016 .^{8_{3}}$ In the Netherlands, the main protagonists in defending the 'Zwarte Piet' tradition (a helper for Saint Nicolas who is painted in

80 Ibid.

81 For example, see: https://tfpheraldos.blogspot.be/; http://trescarabelasaladeriva.blogspot.be; and http://www.angelusonline.org/index.php?section=articles\&subsection=show _article\&article_id=773.

82 Assemblée nationale. 2008. Journal Officiel, 10 June, Question $N^{\circ}$ : 24712, page 4832.

83 https://www.fpec-bxl.be/images-vidéos/ and https://youtu.be/_Zrmkc18VBo. 
black-face and assists delivering candy to children on Saint-Nicolas day in Belgium and The Netherlands) in 2017 and 2018 was the Dutch TFP members Cultuur onder Vuur. ${ }^{84}$ In Lithuania, the TFP Member, Krikščioniškos Kultūros Institutas has led the charge against holding Baltic Pride in Vilnius in 2019 (Repeckaite 2019). The creation in 2017 of TFP Student Action Europe with street protests in Estonia, Ireland and the Netherlands suggest that the network is taking the example of the US-based TFP Student Action to the streets and campuses of Europe. ${ }^{85}$

\subsection{NORM ENTREPRENEUR}

From a protest movement, TFP has evolved into a norm entrepreneur through three approaches: agenda setting, policy expertise and finally engaging in 'law-fare'. First, TFP affiliates convene events to allow for socially conservative agenda-setting. These attract high-level participation for example in Croatia with 'Tradfest'. 'TradFest' takes place annually in Zagreb since 2016 and brings together the conservative representatives of the Church, such as Cardinal Raymond Leo Burke, ${ }^{86}$ with leading politicians such as Davor Ivo Stier, the Deputy Prime Minister of Croatia; Aleksander Stepkowski, former Deputy Minister of Foreign Affairs in Poland (also President of Ordo Iuris Poland); and US Member of Congress Chris Smith, ${ }^{87}$ as well as TFP representatives such as from Poland and Croatia. ${ }^{88}$ Similar events take place at the TFP EU headquarters in Brussels where practically all the conservative currents active in European institutions participate in our events; both the elite of the very cosmopolitan society of Brussels today, and the high Belgian nobility. ${ }^{89}$ These events in turn serve a related purpose to favor the formation of conservative coalition networks in several areas: right to life, family, religious values etc ${ }^{90}$ as per TFP's accredited representative to the EU Institutions.

As second tool in TFP's norm-setting repertoire is that of developing policy and legislative campaigns. Echoing the TFP of the 1970's and 8o's,

\footnotetext{
84 https://cultuurondervuur.nu/tag/zwarte-piet/

85 https://tfpstudentactioneurope.org/

86 For more on Cardinal Burke's conservative positioning within the Vatican (Feder and Hall 2014).

87 Congressman Chris Smith is a leading anti-SRR voice in the US Congress. See his record: http://www.ontheissues.org/NJ/Christopher_Smith_Abortion.htm.

88 http://www.tradfest.org/en/tradfest-2016-en and http://www.tradfest.org/en/tradfest2017-en/.

89 Interview with Paul, Duke of Oldenburg, 10 May 2012: http://www.nobility.org/2012/o5/10/ interview-oldenburg.

90 Ibid.
} 
the campaigns are aimed at the public defamation of progressive, left-wing governments (see examples of France and Spain in section 4.1). Hazte Oir updated the TFP-Covadonga work with a similar publication in 2010 entitled Proyecto Zapatero: Cronica de un asalto a la sociedad. ${ }^{91}$ In Proyecto Zapatero, Hazte Oir explains how secularism, relativism and gender ideology comprise the key ingredients of a grand social engineering experiment by the Socialist Party resulting in undermining the Spanish State. The Hazte Oir President then went on a book tour to promote Proyecto Zapatero and was hosted by the TFP headquarters for its Brussels launch ${ }^{2}$ and by the TFP successor organization in Chile. ${ }^{93}$

The more advanced organisations have evolved to acquire the legal expertise to develop specific policy asks such as proposals to restrict abortion in Poland and Spain. The draft legislation in Poland was prepared and defended by Ordo Iuris ${ }^{94}$ and inspired by Hazte Oir's 'Aborto Cero' campaign in the case of Spain. However, after mass demonstrations in each country, both bills were subsequently withdrawn by their respective governments (BBC 2014, Domonoske 2016).

Most recently, TFP members have embarked upon weakening protections for gender-based violence by campaigning against the Council of Europe Istanbul Convention on gender-based violence. ${ }^{95}$ Ordo Iuris has also drafted an alternative to the Istanbul Convention, the Convention on the Rights of the Family, ${ }^{96}$ which it launched in the European Parliament in October 2018 and is supported by TFP affiliates from Eastern Europe. Separately, in Madrid, Hazte Oir launched its bus against "Feminazis" in March 2019, calling for a review of Spain's gender based violence law. ${ }^{97}$ Ordo Iuris is also an active participant in the informal anti-SRR advocacy network which emerged in 2013 entitled Agenda Europe, even hosting the Agenda Europe summit in Warsaw in 2016 (Datta, 2018). Agenda Europe Summits would allow other similarly conservative minded organisations

91 Arsuaga Rato, Ignacio, and Miguel Vidal Santos. 2010. "Proyecto Zapatero: Cronica de un asalto a la sociedad." HazteOir website.

92 http://www.hazteoir.org/evento/39o Arsuaga Rato, Ignacio, and Miguel Vidal Santos. 2010. "Proyecto Zapatero: Cronica de un asalto a la sociedad." HazteOir website.74-muevetechile-invita-ignacio-arsuaga-hablar-ho-y-proyecto-zapatero.

93 Ibid.

94 See dossier Równa ochrona prawna dla każdego dziecka zarówno przed, jak i po urodzeniu: http://www.ordoiuris.pl/sites/default/files/pliki/OI\%2obroszura\%2oStop\%2oa borcji_final_rozkladowki.pdf.

95 https://ordoiuris.pl/pliki/dokumenty/opinia-Łotwa.pdf.

96 http://en.ordoiuris.pl/family-and-marriage/convention-rights-family-international-guarantee-defence-families

97 El Pais. 2019. Spanish ultraconservative group launches bus campaign against "feminazis" 1 March. 
and individuals outside the TFP network to learn from TFP's policy innovations and domesticate them to their context..$^{98}$

A most sophisticated level of engagement is that of initiating 'lawfare' (Yamin, et. al. 2018), namely using legal strategies such as litigation and engaging with human rights bodies at national, European and international level. Thus, in February 2017, Ordo Iuris obtained Consultative Status with the United Nations (UN ECOSOC. 2017) and by May 2017 had registered an office in the EU district of Brussels. ${ }^{99}$ The newly created Ordo Iuris-Croatia had already secured a place on the working group with the Croatian government tasked with implementing the Council of Europe Istanbul Convention on gender-based violence in 2017 (Despot 2017). In Poland, Ordo Iuris has been active before the Polish courts end expanded internationally by successfully supporting the case of a Norwegian national obtaining asylum in Poland to escape the influence of the Child Protection Services. ${ }^{100}$

\section{7·3. INFILTRATING DECISION-MAKING SPACES}

Infiltrating decision-making spaces is another objective of TFP-affiliates with historical precedents in Latin America ${ }^{101}$ and contemporary examples in Europe. For example, Roberto de Mattei, who considers himself $a$ disciple of Professor Plinio Corrêa de Oliveira... and to whom he dedicated a biography, ${ }^{102}$ was appointed International Affairs Counsel in the government of Silvio Berlusconi from 2002 to 2006. Another example is Massimo Introvigne, who leads one of the TFP groups in Italy, is a student of the TFP founder ${ }^{103}$ and was appointed in 2011 as Personal Representative of the OSCE Chairperson-in-Office on Combating Racism, Xenophobia and Discrimination, also Focusing on Intolerance and Discrimination against Christians and Members of Other Religions. ${ }^{104}$ Using the credibility of this position, Introvigne asserted that [t] he most dangerous areas [of intole-

98 For example, Ordo Iuris mentions having presented its Convention on the Rights of the Family at the 2018 Agenda Europe Summit in Vienna, see http://en.ordoiuris.pl/family-andmarriage/convention-rights-family-international-guarantee-defence-families

99 See the Ordo Iuris Brussels office: http://www.ordoiuris.pl/en/node/98.

100 http://en.ordoiuris.pl/family-and-marriage/asylum-silje-garmo-officially-confirmed.

101 Gonzalez Ruiz (2006) who explains how, in the 1970s, a TFP member from Argentina served as his country's ambassador to Brazil and the United Nations and how another Peruvian TFP member rose to the position of Vice-Chancellor and First Vice-President under President Fujimori.

102 http://www.robertodemattei.it/en.

103 http://www.massimointrovigne.com.

1049 Colonne. 2011. "OSCE, Massimo Introvigne nuovo rappresentante lotta al razzismo". 9 Colonne, 10 January. 
rance and discrimination] are those which limit the conscientious objection of Christians who do not want to cooperate in abortion, the sale of abortifacient pills, or the celebration of same-sex marriage. (White 2013a).

Having barely established themselves in Croatia, the TFP organizations have already progressed significantly, with a member of the TFP organization serving as foreign policy advisor to the Prime Minister until 2016. ${ }^{105}$ More recently, in the Polish government of Prime Minister Szydlow in 2015, Aleksander Stepkowski, President of Ordo Iuris Poland, was appointed Deputy Minister of Foreign Affairs. ${ }^{106}$ Stepkowski held this function from 2015 to 2016, during which time he paved the way for the draft abortion ban to make its way through the wheels of government. In February 2019 Stepkowski was confirmed as a judge on the Polish Supreme Court (Jałoszewski 2019).

Separately, an additional manner to reach influential positions is to court like-minded political parties or, when necessary, to create them. Thus, the far-right parties of Lithuania (Pro Patria) ${ }^{107}$ and Belarus (Беларускі Народны Фронт / Belarus Peoples' Front) ${ }^{108}$ have open links with TFP, while the new VOX party of Spain shares an overlapping leadership with Hazte Oir (Bastante 2018) and the a candidate for the 2019 federal elections of the Belgian Vlams Belang has participated in TFP Summer academies in Poland (see section 4).

\subsection{TFP'S CHEQUERED PAST IS CATCHING UP}

Finally, TFP's past seems to be catching up with it. The recent success and notoriety that some in the TFP franchise have achieved, particularly Vigilare and Ordo Iuris, have attracted the attention of investigative journalists. In Poland, Wyborcza published several accounts in 2017 of Ordo Iuris, outlining how it is related to "a Brazilian cult" (Piątek 2017). This generated a media spotlight on the organization and the influence it wielded on the ruling PiS party (Gruca 2017). Meanwhile, in Croatia, in May 2017, investigative journalists published articles describing the Croatian TFP organizations' previously unknown links with TFP (Despot 2017). On further investigation, journalists uncovered how the individuals involved

105 The advisor, Stjepo Bartulica, is a member of the TFP organization Centar za obnovu kulture (Penić 2016).

106 http://msz.gov.pl/pl/aktualnosci/wiadomosci/aleksander_stepkowski_podsekretarzem_stanu_w_msz.

107 http://www.propatria.lt/2018/12/dovilas-petkus-ko-mes-dar-nesupratome.html retrieved 16 March 2019.

108 http://narodny.org/ retrieved 16 March 2019 and Szoszyn, Rusłan. 2016. "Polak-katolik" w białoruskim parlamencie? Rzeczpospolita. 6 September. 


\section{6 \\ POLITIČKE PERSPEKTIVE \\ ČLANCI I STUDIJE}

in Vigilare are part of a wider anti-Semitic, 'alt-right' community (Benačić 2017). This revelation led to a loss of credibility for a prominent member of Vigilare, forcing him to halt all public engagement by deleting his social media accounts and resigning as a regular commentator on Croatian television (Šimićević 2017). Even the religious wing of TFP, the Heralds of the Gospel, which had mended its relationship with the Vatican, is in turmoil, as revelations appeared in June 2017 of inappropriate religious practices and threats to the life of Pope, thus provoking an internal investigation for apostasy by Vatican bodies (Tornielli 2017).

\section{CONCLUSION}

Then the great leaders of human masses rose up and began to drag behind them the multitudes terrorized into a state of delirium, and to promise simple solutions through the most diverse legislative reforms.

Plinio Corrêa de Oliveira

Section on Dictatorships, In Defense of Catholic Action, 1943 (Corrêa de Oliveira 1943)

There are several conclusions to draw from an understanding of TFP. The first is that TFP's chameleon nature has successfully shielded it from public scrutiny in Europe for a long time. This is changing as more investigative journalists, activists and researchers attempt to understand the organisations behind a number of anti-SRR policy initiatives in Europe. As these investigations take place, it becomes apparent that story TFP did not end with the death of the founder and the creation of the Heralds of the Gospel.

The second conclusion is that the story of TFP is now a European story. After a lull in the early $21^{\text {st }}$ century, the TFP network has emerged from slumber, modernized and expanded to new territories. Indeed, the movement has transformed itself and has found new horizons in Europe, with recent progress in Poland, Croatia and Estonia. It has also updated its infrastructure by setting up an office to lobby the EU, an institute of higher learning in France, as well as a team of lawyers based in Poland. In its original Brazil TFP is but a shadow of what it once was... with valuable assets such as land and some real estate, as well as a structured mailing services that distributes medals and collects donations, the entity has lost relevance and is no longer a reference in Brazil's conservative agenda (ISTOE 2013). In some parts of Europe TFP affiliated organisations are now the centre of gravity in pushing positions which go against SRR.

TFP's position within the Catholic world also merits attention. When the Church hierarchy was sufficiently conservative, its role as an insurrection 
movement tempered. Now, under the progressive reign of Pope Frances, TFP's traditionalist oriented critiques are resurfacing and they are finding allies with like-minded factions within the Church. This suggest that there is also competition with other, more mainstream Vatican-oriented, socially conservative movements for agenda setting against SRR.

The TFP network possesses a recognizable toolkit to achieve its objectives. The chief among them is public mobilization involving religious campaigns through mass communications. Another component is that of setting the political debate by developing legislative packages and of demonizing progressive governments. This legislative experience has culminated in the creation of permanent legal expertise which is engaging is in 'lawfare' at national as well as international level. A standard in the TFP repertoire is leadership infiltration, with several TFP-affiliated individuals gaining access to influential political positions.

The current populist, reactionary and nationalist trend in Europe, often intertwined in religious discourse, offers fertile ground and familiar territory for TFP franchises to take their crusade further, cultivate new allies and, thus, have greater impact. More ominous is the depth of infiltration by Ordo Iuris into the workings of the Polish State, with the current hardright, ethno-nationalist government's embrace chillingly reminiscent of TFP's glory days with Latin American fascist regimes. Finally, TFP's reactionary narrative espousing religious orthodoxy and sanctifying economic inequality by invoking a heroic and noble imaginary past could become attractive to some by offering religious legitimization for illiberalism and authoritarianism, as it did in Latin America in the 1960s to 1990s. Alternatively, understanding TFP's origins and history through time and across continents and the movement's contempt for women and the poor, the extolling of wealth as part of its ideology (Gruca 2007) could prove to be the TFP crusader's Achilles heel.

\section{REFERENCES}

\section{ACADEMIC LITERATURE}

Barker, Eileen. 2010. The cult as a social problem. In: Hjem, Titus, (ed.) Religion and social problems. Routledge Advances in Sociology. Routledge, New York, USA, pp. 198-212.

Calcano de Temeltas, Josefina, Magistrada de la Corte Suprema de Justicia. 1999.

"Tratamiento de los Derechos Humanos en la Jurisprudencia de la Corte Suprema de Justicia”. Revista de la Facultad de Ciencias Juridicas y Politicas 111. Caracas: Universidad Central de Venezuela. 


\section{8 \\ POLITIČKE PERSPEKTIVE \\ ČLANCI I STUDIJE}

Compagnon, Olivier. 2008. "Le 68 des catholiques latino-américains dans une perspective transatlantique”. Paper presented at 'Les deux rives latines de mai 68', MAL, 2 June 2008. http://nuevomundo.revues.org/47243\#tocto2n3 (access 1. 5. 2019).

Garbagnoli, Sara. 2017. "Italy as a lighthouse; Anti-gender protests between the 'anthropological question' and national identity”. In: Anti-Gender Campaigns in Europe, edited by Roman Kuhar and David Paternotte, Chapter 9. Lanham, MD: Rowman and Littlefield International.

Gonzaléz Ruiz, Édgar. 2006. Cruces y Sombras, Perfiles del conservadurismo en America Latina, 1st edition. San José: Asociación Colectiva por el Derecho a Decidir. https://programaddssrr.files.wordpress.com/2013/o5/cruces_y_sombras-versiczb3n-colectiva-por-el-derecho-a-decidir.pdf

Gonzaléz Ruiz, Édgar. undated. MURO (Movimiento Universitario de Renovadora Orientación) Memorias y Testimonios 1961-2002. Puebla: Benemérita Universidad Autónoma de Puebla. https://www.researchgate.net/publication/31732941_ MURO_memorias_y_testimonios_1961-2002_E_Gonzalez_Ruiz.

Introvigne, Massimo. 2009. "TFP and the Heralds of The Gospel: The Religious Economy of Brazilian Conservative Catholicism”. Paper presented at the 2009 Meeting of the Association for the Study of Religion, Economics, and Culture (ASREC), Washington, DC, 2-5 April 2009. http://www.thearda.com/asrec/archive/papers/Introvigne\%20-\%2oTFP\%2oand\%2othe\%2oHeralds\%2oof\%2oT he\%20Gospel\%20-\%20ASRECog.doc.

Kemper, Andreas. 2015. "Christlicher Fundamentalismus und neoliberal-nationalkonservative Ideologie am Beispiel der 'Alternative für Deutschland”. In: Ed. Lucie Billmann. Unheilige Allianz Das Geflecht von christlichen Fundamentalisten und politisch Rechten am Beispiel des Widerstands gegen den Bildungsplan in Baden-Württemberg. Rosa Luxembur Stiftung. https://www.rosalux. de/fileadmin/rls_uploads/pdfs/Materialien/Materialien8_Unheilige_Allianz. pdf (access 17. 5. 2019).

Kuhar, Roman, Paternotte, David. 2017. Anti-Gender Campaigns in Europe. Lanham, MD: Rowman and Littlefield International.

Matta, Raúl. 2008. “Tradition, Famille et Propriété: Une enquête sur les 'croisés' du XXIe siècle”. L'Ordinaire Latino-Américaine (210): 121-137. ISSN o997-0584 (in French).

Mayer N. Zald. 1982. “Theological Crucibles: Social Movements in and of Religion”. Review of Religious Research, Vol. 23, No 4 (June, 1982), pp. 317-336.

Peñas Defago, María Angélica; Morán Faúndes, José Manuel, Vaggione, Juan Marco. 2018. "Religious conservatism on the global stage: threats and challenges for LGBTI rights”. November, Global Philanthropy Project. https://globalphilanthropyproject.org/2018/11/o4/religious-conservatism-on-the-global-stagethreats-and-challenges-for-lgbti-rights/ 
NEIL DATTA

MODERN-DAY CRUSADERS IN EUROPE. TRADITION, FAMILY AND PROPERTY: ANALYSIS OF A TRANSNATIONAL, ULTRA-CONSERVATIVE, CATHOLIC-INSPIRED INFLUENCE NETWORK

Power, Margaret. 2010. Transnational, Conservative, Catholic, and Anti-Communist: Tradition, Family, and Property (TFP), New Perspectives on the Transnational Right. New York: Palgrave Macmillan US, pages 85-105. https://link.springer. com/chapter/10.1057\%2F9780230115521_5.

Ruderer, Stephan. 2012. "Cruzada contra el comunismo. Tradición, Familia y Propiedad (TFP) en Chile y Argentina”. Sociedad y religión 22(38), Jul.-Dec. http:// www.scielo.org.ar/scielo.php?pid=S1853-70812012000200004\&script=sci_arttext. (access 1. 5. 2019).

Yamin, Alicia Ely, Datta, Neil, Andion, Ximena. 2018. "Behind the Drama: The Roles of Transnational Actors in Legal Mobilization over Sexual and Reproductive Rights". The Georgetown Journal of Gender and Law, Vol XIX/533.

Zanotto, Gizele. 2007. “Tradição, família e propriedade (TFP): as idiossincrasias de um movimento católico (1960-1995)”. Doctoral thesis. Florianópolis: Universidade Federal de Santa Catarina (in Portuguese).

\section{OFFICIAL DOCUMENTS}

Assemblée nationale. 1995. Rapport fait au nom de la Commission d'enquête (1) sur les sectes, Rapporteur M. Jacques Guyard, 20 décembre 1995. Paris: Assemblée nationale. http://www.assemblee-nationale.fr/rap-enq/r2468.asp\#ici.

Assemblée Nationale. 1999. Les sectes et l'argent, $N^{\circ} 1687$, Rapport fait au nom de la Commission d'enquête sur la situation financière, patrimoniale et fiscale des sectes ainsi que leurs activités économiques et leurs relations avec les milieux économiques et financiers, 10 juin 1999, Rapporteur M. Jean-Pierre Brard. Paris: Assemblée nationale. http://www.assemblee-nationale.fr/dossiers/sectes/ sommaire.asp.

Assemblée nationale. 2008. Journal Officiel, 10 June, Question $N^{\circ}:$ 24712, page 4832. http://questions.assemblee-nationale.fr/q13/13-24712QE.htm.

Bezerra, Elton. 2013. Estatuto em questão, Disputa por controle da TFP deve ser decidida no STF, Consultor Juridico, 11 March. https://www.conjur.com.br/2013mar-11/disputa-controle-tfp-decidida-supremo

Mariani, Thierry. 2009. "Question N: 24712 de M. Mariani Thierry, Question publiée au Journal Officiel le: 10/o6/2008, page: 4832; Réponse publiée au Journal Officiel le: 10/02/2009, page: 1363". Assemblée nationale website. http://questions.assemblee-nationale.fr/q13/13-24712QE.htm.

Ministry for Foreign Affairs, Republic of Poland. 2015. "Aleksander Stępkowski podsekretarzem stanu w MSZ”. Ministry for Foreign Affairs website, 30 November. http://msz.gov.pl/pl/aktualnosci/wiadomosci/aleksander_stepkowski_podsekretarzem_stanu_w_msz.

Mission interministérielle de vigilance et de lutte contre les dérives sectaires (MIVILUDES). 2006. Rapport au Premier ministre 2006 - L'approche économique 
des mouvements à caractère sectaire. Buchelay: UNADFI. http://www.unadfi. org/system/files/articles/rapport_miviludes_2006_-_TFP.pdf.

Immigration and Refugee Board of Canada. 1998. Venezuela: Information on a religious para-military group called 'Family, Tradition and Property' (TFP). VEN29055.E. Ottawa: Immigration and Refugee Board of Canada, 1 April. http://www.refworld.org/docid/zae6abee6o.html.

Sentencia, Ordinario 1313/2013, juzgado de primero instancia, $\mathrm{N}^{\circ} 48$, Madrid, of 22 May 2014

UN ECOSOC. 2017. Non-Governmental Organizations Committee Recommends 49 Groups for Consultative Status. ECOSOC/6810-NGO/843, 1 February 2017. New York: UN ECOSOC. https://www.un.org/press/en/2017/ecosoc6810.doc.htm.

Venezuela Ministerio Público. 1984. Informe FGR. Caracas: Ministerio Público, pages 292-306. http://catalogo.mp.gob.ve/min-publico/doctrina/php/buscar.p $\mathrm{hp}$ ?base $=$ doctri\&cipar $=$ doctri.par\&epilogo $=\&$ Formato $=\mathrm{w} \& O$ pcion $=$ detalle $\& \mathrm{E}$ xpresion $=\mathrm{N}: 304$.

\section{NEWS ARTICLES}

Agente Provocador. 2017. 'Los 'caballeros medievales' de Covadonga son peores que Hazte Oír." Agente Provocador, 8 March 2017. http://www.agenteprovocador.es/publicaciones/hazte-oir-poda-ser-peor.

Bastante, Jesús. 2015. "El Obispado de Getafe confirma la prohibición a Hazteoir y Derecho a Vivir a utilizar la diócesis para promover sus actividades”. Religión Digital website, 10 March. http://www.periodistadigital.com/religion/espana/2015/o3/10/el-obispado-de-getafe-confirma-la-prohibicion-a-hazteoir-yderecho-a-vivir-utilizar-la-diocesis-para-promover-sus-actividades.shtml.

Bastante, Jesús. 2018. Las conexiones de Vox con HazteOir, los 'kikos' y una docena de obispos españoles. El Diario. 7 December. https://www.eldiario.es/sociedad/conexiones-Vox-grupos-ultracatolicos_o_843766322.html

BBC. 2016. "Black Monday: Polish women strike against abortion ban”. BBC website, 3 October. http://www.bbc.com/news/world-europe-37540139.

BBC. 2014. "Spain abortion: Rajoy scraps tighter law”. BBC website, 23 September. https://www.bbc.com/news/world-europe-29322561

Benačić, Ana. 2017. “Trostruka zagrada Luke Popova”. Faktograf, 15 May. http://faktograf.hr/2017/05/15/trostruka-zagrada-luke-popova.

Cesnur.org. 2001. "Anti-Cult Campaigns: Chile Threatens to Follow France”. CESNUR website, 1 July. http://www.cesnur.org/2001/chile_july_o1.htm

Cochez, Tom. 2019. "Het duistere netwerk achter Dries Van Langenhove”. Apache.be website, 14 January. https://www.apache.be/2019/o1/14/het-duistere-netwerkachter-dries-van-langenhove/?sh=doo154ce4d68e86oc5c3a-226oo6594 
Cariello, Rafael. 20o8. "Sem nome, TFP tenta manter ação política”. Folha de S. Paolo, 13 December. http://www1.folha.uol.com.br/fsp/brasil/fc1312200811.htm.

Domonoske, Camila. 2016. "After Protests, Polish Legislators Vote To Reject Abortion Ban”. NPR website, 5 October. https://www.npr.org/sections/thetwoway/2016/10/o5/496722248/after-protests-polish-legislators-vote-to-rejectabortion-ban?t=1553527343823

Despot, Sanja. 2017a. „Borba protiv nasilja nad ženama bit će žrtva 'pluralističke’ radne skupine”. Faktograf, 8 March. http://faktograf.hr/2017/o3/o8/borba-protiv-nasilja-nad-zenama-bit-ce-zrtva-pluralisticke-radne-skupine/.

Despot, Sanja. 2017b. „TFP: Srednjovjekovni upliv u rad Vlade”. Faktograf, 11 May. http://faktograf.hr/2017/o5/11/tfp-vigilare-srednjovjekovni-upliv-u-rad-hrvatske-vlade/.

El Pais. 2019. Spanish ultraconservative group launches bus campaign against "feminazis" 1 March. https://elpais.com/elpais/2019/o3/o1/inenglish/1551428604_ 932895.html

El Plural. 2017. “'El Yunque', la sociedad paramilitar vinculada con HazteOír, cada vez menos secreta”. El Plural, 3 February. http://www.elplural.com/comunicacion/2017/02/o3/el-yunque-la-sociedad-paramilitar-vinculada-con-hazteoir-cada-vez-menos.

Feder, J. Lester, and Ellie Hall. 2014. "Conservative Cardinal Who Clashed With Pope Francis Confirms He Has Been Ousted”. Buzzfeed, 17 October. https:// www.buzzfeed.com/lesterfeder/conservative-cardinal-who-clashed-with-popefrancis-confirms?utm_term=.jgDpVmLpD\#.rqqz52Kzi.

Gruca, Radosław. 2017. "Brazylijska sekta szantażuje PiS? Chodzi o całkowity zakaz aborcji”. FAKT24.pl website, 28 March. http://www.fakt.pl/wydarzenia/polityka/tomasz-piatek-ordo-iuris-jest-powiazane-z-brazylijska-sekta-wplywana-pis/szkgzvr.

ISTOE. 1984. TFP Composition, Political Orientation, Training Discussed. Sao Paulo: ISTOE, pages 18-23 (in Portuguese); published in Foreign Broadcasting Information Service. 1985. Latin America Report. FBIS, 15 May.

ISTOE. 2013. “A nova TFP”. ISTOE website, 29 November, updated 21 January 2016. http://istoe.com.br/337199_A+NOVA+TFP.

Jałoszewski, Mariusz. 2019. Założyciel Ordo Iuris wchodzi do Sądu Najwyższego. To już drugi aktywista tej formacji w SN. Oko Press, 21 January. https://oko. press/zalozyciel-ordo-iuris-wchodzi-do-sadu-najwyzszego-to-juz-drugi-aktywista-tej-formacji-w-sn/

Jimenez Jacinto, Juan Francisco. 2015. “Entrevista a Victoria Uroz (I): 'El Yunque es el mayor problema al que se enfrentan los laicos católicos en España”. Forum Libertas, 9 January. http://www.forumlibertas.com/entrevista-a-victoriauroz-i-el-yunque-es-el-mayor-problema-al-que-se-enfrentan-los-laicos-catolicos-en-espana. 
Despot Sanja. 2017. „Hrvatska protiv pobačaja, uz Trumpa, u društvu s Poljskom i Mađarskom”. Faktograf (26. 2. 2017.), http://faktograf.hr/2017/o2/26/ljudskaprava-hrvatska-protiv-pobacaj/ (pristup 1. 5. 2019). English translation at: Kuća ljudskih prava Zagreb. 2017. "Croatia against abortions, alongside Trump, Poland and Hungary”. Kuća ljudskih prava Zagreb, 26 February. http://www.kucaljudskihprava.hr/2017/o2/26/croatia-abortions-alongside-trump-polandhungary (access 1. 5. 2019).

La Depèche. 2003. “Une nouvelle affaire de secte?” La Depèche, 23 January. https:// www.ladepeche.fr/article/2003/o1/23/289628-une-nouvelle-affaire-de-secte. html.

Navarro, Ernesto J. 2004. “TFP quiso asesinar al Papa en Venezuela”. Aporrea, 10 June. https://www.aporrea.org/actualidad/a8513.html.

Palmer, Daniele. 2017. "Vatican investigates Catholic group after exorcism claim that Francis is devil's man”. The Tablet, 26 June. http://www.thetablet.co.uk/ news/7367/o/vatican-investigates-catholic-group-after-exorcism-claim-thatfrancis-is-devil-s-man.

Penić, Goran. 2016. „Premijerov savjetnik i član Opusa Dei Stjepo Bartulica: Zašto sam bio na 'Hodu za život”. Jutarni Vijesti, 23 May. http://www.jutarnji.hr/vijesti/hrvatska/premijerov-savjetnik-i-clan-opusa-dei-stjepo-bartulica-zastosam-bio-na-hodu-za-zivot/4068423.

Piątek, Tomasz. 2017a. "Ordo Iuris i brazylijska sekta. Kim są obrońcy życia od samego poczęcia”. Wyborcza, 27 March. http://wyborcza.pl/7,75968,21554217,ordoiuris-i-brazylijska-sekta-kim-sa-obroncy-zycia-od-samego.html?disableRedi rects=true.

Piątek, Tomasz. 2017b. “Ordo Iuris, sekta z Brazylii i... dygnitarze Putina”. Wyborcza, 7 May. http://wyborcza.pl/7,75968,21605548,ordo-iuris-sekta-z-brazyliii-dygnitarze-putina.html.

Piątek, Tomasz. 2017c. "TFP i książęta Hitlera”. Wyborcza, 14 May. http://wyborcza.pl/7,75968,21638150,tfp-i-ksiazeta-hitlera.html.

Repeckaite, Daiva. 2019. International funds power up Christian NGOs. 11 March. NewsMavens, Lithuania. https://newsmavens.com/special-review/1081/international-funds-power-up-christian-ngos?fbclid=IwAR3xde7TogPN3JtFfwqpN WSo3Tv3EazVUAL-ofwTPmKb7uQCI6ZJsYEAquQ

Severo, Richard, 2019. "Lyndon LaRouche, Cult Figure Who Ran for President 8 Times, Dies at 96”. New York Times, 13 February. https://www.nytimes. com/2019/02/13/obituaries/lyndon-larouche-dead.html

Šimičević, Hrvoje. 2017. "Luka Potop”. Portal Novosti, 26 May. http://www.portalnovosti.com/luka-potop.

Szoszyn, Rusłan. 2016. "Polak-katolik" w białoruskim parlamencie? Rzeczpospolita. 6 September. https://www.rp.pl/Polityka/16o909447-Polak-katolik-w-bialoruskim-parlamencie.html 
Tornielli, Andrea. 2017a. "Heralds of the Gospel, The founder leaves while the Vatican investigates". Vatican Insider, La Stampa, 13 June. http://www.lastampa. it/2017/o6/13/vaticaninsider/eng/inquiries-and-interviews/heralds-of-the-gospel-the-founder-leaves-while-the-vatican-investigates-V8amQiCVIP9mJ3hwRa3F2I/pagina.html.

White, Hilary. 2013a. "Christians are the most persecuted group in the world, expert says". LifeSiteNews, 31 May. https://www.lifesitenews.com/news/christians-arethe-most-persecuted-group-in-the-world-expert-says.

White, Hilary. 2013b. "Estonian same-sex partnership stalled after family campaigners presented 38,ooo signatures”. LifeSiteNews, 10 June. https://www.lifesitenews.com/news/estonian-same-sex-partnership-stalled-after-family-campaigners-presented-38 (access 1. 5. 2019).

Wyputta, Andreas. 2016. "Das Haus Oldenburg und die Nazis, Eine schrecklich braune Familie”. Taz.de website, 5 December. http://www.taz.de/!5359430/.

9 Colonne. 2011. "OSCE, Massimo Introvigne nuovo rappresentate lotta al razzismo”. 9 Colonne, 10 January. http://9colonne.it/25793/osce-massimo-introvigne-nuovo-rappresentante-lotta-al-razzismo\#.WNfpHoVOLIU.

\section{TFP AND RELATED WRITINGS}

Arsuaga Rato, Ignacio, and Vidal Santos, Miguel. 2010. "Proyecto Zapatero: Cronica de un asalto a la sociedad". HazteOir website.

Blackwell, Morton C. 2010. "Foreword". In: Corrêa de Oliveira, Plinio. 1993. Nobility and Analogous Traditional Elites in the Allocutions of Pius XII. York, PA: Hamilton Press.

Catolicismo. 1984. "Atentado contra sede da TFP chilena". Catolicismo 34(40o), April, page 12. http://www.pliniocorreadeoliveira.info/GES_19840314_Chileatentadoasede.htm.

Corrêa de Oliveira, Plinio. 1943. In Defense of Catholic Action. Section on Dictatorships, The American Society for the Defense of Tradition, Family and Property, First English Edition October 2006. https://www.pliniocorreadeoliveira.info/UK_ID/ooootable_contents.htm

Corrêa de Oliveira, Plinio. 1959 and 1977. "Revolução e Contra-Revolução". Catolicismo, April 1959 (parts I and II) and January 1977 (part III). http://www.tfp. org/wp-content/uploads/200o/o1/books_rcr.pdf.

Corrêa de Oliveira, Plinio. 1974. Grupos ocultos traman la subversion en la Iglesia - El IDO-CY los groupos profeticos. Madrid: Sociedad Cultural Covadonga. http://www.pliniocorreadeoliveira.info/IDOC_Espanha/1974_IDOC_Espanha.htm\#.WOTmYoVOKUk.

Corrêa de Oliveira, Plinio. 1981. "The Double Game of French Socialism: Gradual in Strategy, Radical in Goal”. The American Society for the Defense of Tradition, 
Family and Property. https://www.tfp.org/the-double-game-of-french-socialism-gradual-in-strategy-radical-in-goal/ (access 1. 3. 2019).

Corrêa de Oliveira, Plinio. 1985. "A Reforma Agrária socialista e confiscatória - A propriedade privada e a livre iniciativa, no tufão agro-reformista”. Plinio Corrêa de Oliveira website. http://www.pliniocorreadeoliveira.info/tufaoooooindice. htm.

Corrêa de Oliveira, Plinio. 1991. "TFPs Undertake Victorious Crusade in Favor of Free Lithuania”. TFP website, 28 June. http://www.tfp.org/tfps-undertake-victorious-crusade-in-favor-of-free-lithuania/.

Corrêa de Oliveira, Plinio. 1993. Nobility and Analogous Traditional Elites in the Allocutions of Pius XII. York, PA: Hamilton Press. https://www.tfp.org/nobility/ and http://www.nobility.org/.

de Mattei, Roberto. 1996. El Cruzado del Siglo XX - Plinio Corrêa de Oliveira (original title: Il Crociato del Secolo XX). Asociación Tradición y Acción por un Perú Mayor. www.tradicionyaccion.org.pe (access 10. 3. 2019).

Nobility org. 2015. "In Memoriam: Marquis Luigi Coda Nunziante". 9 July. http:// www.nobility.org/2015/07/o9/marquis-luigi-coda-nunziante/ (access 10. 3. 2019).

Ordo Juris. undated. Równa ochrona prawna dla każdego dziecka zarówno przed, jak i po urodzeniu. Warsaw: Ordo Juris. http://www.ordoiuris.pl/sites/default/ files/pliki/OI\%2obroszura\%2oStop\%2oaborcji_final_rozkladowki.pdf.

TFP Covadonga. 1988. "España, anestesiada sin percibirlo, amordazada sin quererlo, extraviada sin saberlo - La obra del PSOE”. Covadonga Informa 9 (123), March, April-May. http://www.pliniocorreadeoliveira.info/EA_Livro_completo/GES_EA_Indice_general_Site.htm\#.WOTIBoVOKUm.

TFP-France. 1980. Imbroglio, Detraction, Delire: Remarques sur un Rapport concernant les TFP. Asnières: Tradition, Famille, Propriété (in French). http://www. pliniocorreadeoliveira.info/FR_ImbroglioDetractionDelire_Volo1.pdf.

\section{ACTIVIST LITERATURE}

Datta, Neil. 2018. "Restoring the Natural Order: The religious extremists' vision to mobilize European societies against human rights on sexuality and reproduction”. EPF, 2018. https://www.epfweb.org/sites/epfweb.org/files/rtno_epf_ book_lores.pdf

EIR. 1985. "For an international mobilization to stop the TFP brainwashing cult". EIR 12(5), 5 February. http://www.larouchepub.com/eiw/public/1985/eirv12no519850205/eirv12no5-19850205_028-for_an_international_mobilizatio.pdf.

Fedeli, Orlando. 2010. No país das maravilhas: a Gnose burlesca da TFP e dos Arautos do Evangelho. São Paulo: Monfort Associação Cultural. http://www.montfort.org.br/bra/veritas/religiao/contra-pco. 
fsspx.new. 2017. “Canonical Investigation into the 'Heralds of the Gospel' Following Bizarre Practices”. fsspx.news website, 29 June. http://fsspx.news/en/newsevents/news/canonical-investigation-heralds-gospel-following-bizarre-practices-3080o.

Leroy, Bruno. 1980. “'Tradition-Famille-Propriété’: Une secte influente”. Le journal chrétien, 5 July. http://www.ccmm.asso.fr/spip.php?article1255.

Mata, Santiago. 2015. El Yunque en España: La sociedad secreta que divide a los católicos. Madrid: Ediciones Amanecer

Ortiz, Irene. 20o8. "Building the City of God: Mexico's Ultra-Right Yunque”. The North American Congress on Latin America (NACLA) website, 6 March. https://nacla.org/article/building-city-god-mexicos-ultra-right-yunque.

Tribunal Correctionnel de Chartres. 2001. “Tradition, Famille, Propriété, Avenir de la culture, Groupe inscrit sur la liste des sectes du rapport parlementaire de 1995, Procès 'Européenne de medias' (GEIE) Contre 'L'Echo Républicain de Chartres"'. Echo communication, Audience of 17 September 2001. http://www. prevensectes.com/tfp4.htm.

\section{SAŽETAK}

\section{SUVREMENI KRIŽARI U EUROPI. \\ TRADICIJA, OBITELJ I VLASNIŠTVO: ANALIZA TRANSNACIONALNIH, ULTRAKONZERVATIVNIH, KATOLICIZMOM INSPIRIRANIH MREŽA UTJECAJA}

Tri nedavna događaja koja se tiču seksualnih i reproduktivnih prava (predložena zabrana pobačaja u Poljskoj, blokiranje potpore inicijativi She Decides u Hrvatskoj i zaustavljanje Zakona o civilnom partnerstvu u Estoniji) potaknule su organizacije koje se doimaju poput nacionalne antene transnacionalne, socijalno konzervativne mreže Tradicija, obitelj i vlasništvo (Tradition, Family and Property - TFP). TFP je oznaka za skup međupovezanih konzervativnih i katolicizmom nadahnutih organizacija koje dijele svjetonazor blizak osnivaču TFP-a Plinia Corrêe de Oliveira. Nastao u Brazilu 1960-ih, a zatim proširen svijetom, TFP je već dugo pobunjenički pokret unutar katolicizma, a kojeg odlikuje specifičan način djelovanja kroz spajanje socijalnog konzervativizma, ekonomskog hiperliberalizma i naslijeđe bliskosti s krajnje desnim pokretima. Oslabljen u Latinskoj Americi, TFP je sada aktivna europska mreža s dominantnim stavovima protiv seksualnih i reproduktivnih prava (SRR). Utjecaj TFP-a na seksualna i reproduktivna prava zbiva se putem društvene mobilizacije, normativnog poduzetništva i ulaska u prostore donošenja odluka. TFP-u su se u Istočnoj Europi otvorili novi horizonti i ambicije za utjecaj na Europsku uniju i Ujedinjene narode. Reakcionarni narativ TFP-a, koji promiče pravovjernost i posvećuje ekonomske nejednakosti, mogao bi postati privlačan kao religijska legitimacija iliberalizma i autoritarizma.

KLJUČNE RIJEČI: reproduktivna prava, ultrakonzervativizam, religijski pokreti. 